\title{
Effects of fluoxetine and imipramine in rat fetuses treated during a critical gestational period: a macro and microscopic study
}

\section{Efeitos da fluoxetina e imipramina em fetos de ratas tratadas durante o período crítico da gestação: estudo macro e microscópico}

\author{
Cátia Aline Silva Swerts, ${ }^{1}$ Ana Maria Duarte Dias Costa, ${ }^{1}$ Alessandra Esteves, ${ }^{2}$ Carla Elaine Silva \\ Borato, ${ }^{1}$ Mário Sérgio Oliveira Swerts ${ }^{1}$ \\ 1 Universidade José do Rosário Vellano (UNIFENAS), Alfenas, MG, Brazil \\ 2 Universidade Federal de Alfenas (UNIFAL), Alfenas, MG, Brazil
}

\begin{abstract}
Objective: To evaluate morphological alterations in rat fetuses treated with fluoxetine and imipramine during the "critical" period of gestation. Method: Fifteen female rats were separated into three groups $(n=5)$ and treated with $10 \mathrm{mg} / \mathrm{kg} / \mathrm{day}$ of test substances on the ninth, tenth and eleventh day of pregnancy: G1, fluoxetine; G2, imipramine hydrochloride; G3 (control), saline. On day 21, cesarean sections were performed to release the fetuses, whose bodies were weighed and macroscopically analyzed. The placenta was also weighed. The fetuses were then fixed and their encephala removed and weighed. Sections of the frontal lobe were taken for histological neuron counting. Results: G1 and G2 showed the highest fetal body weight. Placental weight showed statistical differences ( $\mathrm{p}$ 5 0.01): G1 weighed more than G2 and G3. Otherwise, G2 exhibited the highest encephalon weight, statistically differing from G3 (control) and fluoxetine-treated G1 ( $\mathrm{p} \leq 0.01$ ). However, G1 did not statistically ( $\mathrm{p}$ $>0.01$ ) differ from the control group. G3 showed the highest number of neurons per area when compared to G1 and G2 ( $p \leq 0.01)$. Conclusion: The use of antidepressants in rats caused an increase in fetal weight and a decrease in the number of fetal frontal lobe neurons, thus suggesting that the use of antidepressants by pregnant women can induce depression in fetuses due to alterations in their neural development.
\end{abstract}

Descriptors: Antidepressants; Fluoxetine; Imipramine; Pregnancy; Teratogens

\section{Resumo}

Objetivo: Avaliar as possiveis alteraçôes ocorridas em nivel macroscópico e microscópico de fetos de ratas submetidas ao tratamento com fluoxetina e imipramina durante o periodo "crítico" da gestação. Método: Quinze ratas, posteriormente ao acasalamento, foram divididas em três grupos experimentais $(n=5)$ : G1, tratadas com $10 \mathrm{mg} / \mathrm{kg} /$ dia de fluoxetina; G2, tratadas com $10 \mathrm{mg} / \mathrm{kg} /$ dia de cloridrato de imipramina, e G3 (controle), tratadas com $10 \mathrm{mg} / \mathrm{kg} /$ dia de solução fisiológica a $0,9 \%$, no $9^{\circ}, 10^{\circ}$ e $11^{\circ}$ dias de prenhez das ratas. Posteriormente à cesária, no $21^{\circ}$ dia de prenhez, analisou-se macroscopicamente o peso fetal e placentário. Os fetos foram fixados e houve a remoção do encéfalo para pesagem e preparação das lâminas do tecido neuronal para contagem de neurônios do lobo frontal. Resultados: O G1 e G2 apresentaram maior peso fetal. $O G 1$ apresentou maior peso placentário, diferindo do G2 e G3 ( $p \leq 0,01)$. De forma diferente, o G2 possuiu maior peso encefálico, diferindo do $G 3$ e $G 1$ ( $p \leq 0,01)$. G1 não diferiu estatisticamente do grupo controle ( $p>0,01)$. O G3 exibiu maior número de neurônios, por área, do lobo frontal em relação a $G 1$ e $G 2$ ( $p \leq 0,01)$. Conclusão: A adoção dos antidepressivos causou, nos fetos, aumento de peso e redução da contagem de neurônios do lobo frontal, sugerindo que a indicação de antidepressivos às gestantes pode induzir a depressão nos fetos por alteraçôes em seu neurodesenvolvimento.

Descritores: Antidepressivos; Fluoxetina; Imipramina; Gestação; Teratogênios

\section{Introduction}

Although gestation is a physiologic phenomenon, it should be carefully monitored on account of the many physical, hormonal, psychic and social changes that can directly influence a women's mental health. ${ }^{1}$

The increase of estrogen and progesterone levels in pregnancy can cause mood disorders, which can be minor or major depending on the sensitivity of each woman. ${ }^{2}$
Self-medication during pregnancy is a reason for great concern for caregivers due to the disastrous injuries that some drugs can impinge on exposed fetuses. ${ }^{3}$

If administered during the embryonic phase, certain drugs can affect the development of the embryo, which can either be killed or suffer from serious disorders.

The constant and periodic hormonal and organic changes

E-mail: mariosergio.swerts@unifenas.br 
experienced by women during their reproductive cycle may result in serious emotional problems, which, in turn, may require the introduction of drug therapy. The need for treatment may be based on a presentiment relating to the effects of stress, anxiety and depression arising from the evolution of pregnancy, childbirth and future maternal function.

The prescription of antidepressants during gestation has been evaluated with respect to their biosecurity, that is, whether or not they have teratogenic effects on fetuses. ${ }^{4}$

Fluoxetine and imipramine hydrochloride are among the most usually prescribed antidepressants. Fluoxetine belongs to the pharmacological group of the serotonin reuptake selective inhibitors. Because it does not bind to histamine, acetylcholine and epinephrine receptors, it has less analgesic, anticholinergic and cardiovascular effects than the tricyclic antidepressants. Imipramine is a tricyclic antidepressant that inhibits norepinephrine and serotonin reuptake. Also called a mixed reuptake inhibitor, imipramine, which equally inhibits both norepinephrine and the serotonin reuptake, has been used in various forms of depression. ${ }^{5}$

During organogenesis, medication can be teratogenic, thereby causing congenital malformations and serious damages that may lead to abortion. Although, if used during the second and third trimesters, medication is no longer able to produce significant malformations, it can affect the fetus's functional development and growth. ${ }^{6}$

Therefore, it is important to search for possible macro- and microscopic abnormalities in fetuses of rats submitted to fluoxetine and imipramine treatment during the "critical" period of gestation.

\section{Method}

This study was approved by the Unifenas Committee of Ethics in Research under registration number 11A/2006 and carried out at the Unifenas Laboratory of Phytopharmaceuticals and Biology and Physiology of Microorganisms and Laboratory of Pharmacology and Experimental Surgery located in Alfenas, state of Minas Gerais. Fifteen female rats (Rattus norvergicus albinus, Wistar) weighing, in average, $250 \mathrm{~g}$ were obtained from the Unifenas Central Vivarium and were offered feed (Labina Purina $^{\mathrm{TM}}$ ) and water ad libitum every two days.

To accurately determine the first day of pregnancy, rats copulated overnight. The next morning, the first day of pregnancy was determined based on the presence of spermatozoa in vaginal smears with $0.9 \%$ saline.

After copulation, the fifteen rats were kept in autoclaved, individual $30 \mathrm{~cm} \times 20 \mathrm{~cm} \times 13 \mathrm{~cm}$ crystal polyurethane cages (Model GC109PC, Beiramar brand), all of them furnished with a polycarbonate $250 \mathrm{~mL}$ water bottle, an acid-resistant rubber stopper and a straight stainless steel drinking tube (Model BBP 250 , Beiramar brand). The rats were then separated into three groups $(\mathrm{n}=5 \mathrm{each}$ ) and treated intraperitoneally with $10 \mathrm{mg} / \mathrm{kg} /$ day $^{7}$ of the test substances on the ninth, tenth and eleventh day ${ }^{8}$ of pregnancy as follows:

- Group 1: fluoxetine;

- Group 2: imipramine hydrochloride
- Group 3 (control): 0.9\% saline solution.

The administration of $10 \mathrm{mg} / \mathrm{kg} /$ day is equivalent to the dose used for treating anxiety-related disorders, ${ }^{7}$ although other studies have reported that fluoxetine has been prescribed at doses ranging from $8 \mathrm{mg}$ to $16 \mathrm{mg} / \mathrm{kg} /$ day. ${ }^{9}$

On the twenty-first day of pregnancy, the rats were weighed and anesthetized intraperitoneally with xilazine (Rompum ${ }^{\circledR} 20 \mathrm{mg} /$ $\mathrm{mL}$, Bayer) and ketamine hydrochloride (Ketamin-S(+)® 50mg/ $\mathrm{mL}$, Cristália) at a ratio of $1: 3$ at a dose of $0.3 \mathrm{~mL}$ for each $100 \mathrm{~g}$ of animal weight. Through a long abdominal incision, the fetuses were exposed and distributed into 3 groups: 55 in the control group, 62 in the fluoxetine group and 57 in the imipramine hydrochloride group.

The rats were then euthanized in a carbon dioxide chamber.

Fetuses and placentas were separated and fixed during 48 hours in $10 \%$ formaldehyde.

After fixation, the fetuses were kept in $70 \%$ alcohol until the histological processing of the encephala.

To obtain images of the frontal lobe nerve cell bodies, thirty encephala were randomly collected from each group, dehydrated in alcohol, cleared in benzene and embedded in paraffin. With a Leica 2165 microtome, five serial $5 \mu \mathrm{m}$ thick sections were obtained from each block.

These sections were then stained with cresil violet, according to Esteves et al. to specifically dye, in a strong fashion, the Nissl bodies, thus allowing for each nerve cell to be first marked and then counted. ${ }^{10}$

Tissue screening was performed by means of an optical microscope with a 40x objective coupled with a video capture monitor and a counting system. Visual neuron quantification was expressed in numbers per area in a sequential pattern in accordance with Avrushchenko, Michon et al., Rabinowicz et al., and Esteves et al. ${ }^{10-13}$

Five serial sections from the frontal lobe region were selected and ten different fields were screened to produce a mean for statistical analysis. Photomicrographs of the best fields were taken.

\section{Statistical analysis}

The sample data were non-normal, thus indicating the use of the Kruskal-Wallis non-parametric test for independent data to compare the three experimental groups at the $1 \%$ and $5 \%$ significance levels. ${ }^{14}$ Results were processed, and the statistical tests, which were conducted using the 2007 version of the SPSS 15.0 program, were applied to each group by estimating the sample minimum, median, sample maximum, mean and standard deviation. These differences can be explained by the fact that, when comparing groups, no nonparametric confidence (94\%) intervals intercept each other. By nonparametric intervals we mean that [SMin; SMax] is a $94 \%$ confidence interval for the Median.

\section{Results}

On gestational days 9, 10 and 11 rats were intraperitoneally injected with $10 \mathrm{mg} / \mathrm{kg} /$ day of fluoxetine $(\mathrm{G} 1 ; \mathrm{n}=5)$, imipramine hydrochloride $(\mathrm{G} 2 ; \mathrm{n}=5)$ and with $0.9 \%$ physiologic saline solution $(\mathrm{G} 3 ; \mathrm{n}=5)$. 
Table 1 - Weight of fetuses without umbilical cord and placenta (in grams)

\begin{tabular}{|c|c|c|c|c|c|}
\hline & $\begin{array}{c}\text { Sample Minimum } \\
\text { (SMin) }\end{array}$ & Median (Med) & $\begin{array}{c}\text { Sample Maximum } \\
\text { (SMax) }\end{array}$ & $\begin{array}{l}\text { Mean } \\
(\mathrm{M})\end{array}$ & $\begin{array}{c}\text { Standard Deviation } \\
\text { (SD) }\end{array}$ \\
\hline Fluoxetine (G1) & 4003.02 & 4003.03 & 4003.08 & 4003.00 & $0.0246 * *$ \\
\hline Imipramine hydrochloride (G2) & 4100.00 & 4100.05 & 4100.11 & 4100.00 & $0.0426^{* *}$ \\
\hline Control (G3) & 3360.00 & 3360.01 & 3360.08 & 3360.00 & $0.0314^{*}$ \\
\hline
\end{tabular}

Unifenas Laboratory of Phytopharmaceuticals and Biology and Physiology of Microorganisms, 2009.

* indicate $1 \%$ significance level, and ** indicate nonsignificance by the Kruskal-Wallis nonparametric test.

The macroscopic analysis consisted of weighing the fetuses (without their umbilical cord and placenta), the encephala, and the placentas. Combined, the three rat groups carried 174 fetuses: 62 (G1), 57 (G2) and 55 (G3). The fetuses of the imipramine hydrochloride group (G2) weighed more $(4100 \mathrm{mg}$ ) than the others although, statistically speaking, it only differed from group 3 (Kruskal-Wallis test, $\mathrm{p} \leq 0.01$ ) (Table 1). The statistical difference of G2 was visually confirmed by severe alterations in fetal development. Fluoxetine-treated fetuses weighed less than the others although this did not represent a statistically significant difference (Kruskal-Wallis test, $\mathrm{p}>0.01$ ).

While evaluating drug retention, G1 (fluoxetine) placentas weighed more $(403.77 \mathrm{mg}$ ) than those of G2 and G3, whose placentas weighted $367.47 \mathrm{mg}$ and $294.18 \mathrm{mg}$ respectively, a fact which is statistically significant (Kruskal-Wallis test, $\mathrm{p} \leq 0.01$ ) (Table 2).

The encephala were then removed and weighed. The G2 (imipramine) encephala weighed more $(84.96 \mathrm{mg})$ than the others and statistically differed from G3 (control) and G1 (fluoxetine) (Kruskal-Wallis test, $\mathrm{p} \leq 0.01$ ). However, G1 did not statistically differ from G3 (Kruskal-Wallis test, p > 0.03) (Table 3).

The same encephala were sectioned and histologically processed for neuron counting in the frontal lobe, which plays an essential role in behavior. Results showed evident neat differences between the treated groups and the control. An interesting observation was that G3 exhibited more neurons per area of the frontal lobe i.e., 36.61 against 34.38 of G1, and 28.11 of G2, these differences being, therefore, statistically significant (Kruskal-Wallis test, $\mathrm{p} \leq 0.01$ ) (Table 4).

Nervous tissue degeneration was observed in groups G1 and G2; however, the latter showed less neuroglial tissue and wider spaces between neurons, thus suggesting a reduction in the number of nerve cells. Tissue degeneration was also evident in G1, although with a stronger presence of neurons compared to G2.

The imipramine-treated group also revealed edematous neurons and dilation of blood vessels. No such alterations were found in G3 (control).

\section{Discussion}

Pregnancy should be carefully evaluated given that it is a period during which women go through many physical, hormonal and psychic changes which, in turn, influence their mental health. ${ }^{1}$ Lately, it has been recognized that gestation can be complicated by emotional problems such as depression, thus heavily impacting both mother and fetus. ${ }^{15}$

The use of medication during pregnancy requires special attention due to the potential risks to the developing fetus. Pregnant women often need psychiatric treatment in face of emotional disorders caused by stress, anxiety and depression.

Antidepressants are capable of crossing the placental barrier, and their use has been evaluated with respect to their biosecurity. Recent researches report the use of tricyclic antidepressants and serotonin reuptake inhibitors, especially fluoxetine, in pregnant women. Some authors have proposed new studies to assess the risk-benefit ratio of the use of antidepressants during gestation. ${ }^{16,17}$ Likewise, serotonin and noradrenaline are involved in the physiopathology of affective disorders. ${ }^{18}$ Imipramine inhibits noradrenaline and serotonin reuptake in the central nervous system, ${ }^{19}$ while fluoxetine selectively inhibits serotonin reuptake. ${ }^{20}$

This study evaluated the possible macroscopic alterations i.e., weight of the fetuses, placentas and encephala and the microscopic alterations i.e., the quantification of frontal lobe nerve cells seen in the fetuses of rats intraperitoneally injected with $10 \mathrm{mg} / \mathrm{kg} /$ day of fluoxetine and imipramine hydrochloride on the $9^{\text {th }}, 10^{\text {th }}$ and $11^{\text {th }}$ day of pregnancy.

Fluoxetine was selected for being the antidepressant of choice for pregnant women while ${ }^{13,21}$ imipramine was chosen for being a tricyclic antidepressant known to be potentially teratogenic. ${ }^{22,23}$

The intraperitoneal route was chosen for being more secure, for providing a faster absorption by the rich blood supply of the large peritoneal area, for not presenting traumatic risks during administration and for constituting a routine laboratory procedure. $^{24}$

Table 2 - Placental weight (in milligrams)

\begin{tabular}{lccccc}
\hline & $\begin{array}{c}\text { Sample Minimum } \\
\text { (SMin) }\end{array}$ & Median (Med) & $\begin{array}{c}\text { Sample Maximum } \\
\text { (SMax) }\end{array}$ & $\begin{array}{c}\text { Mean } \\
\text { (M) }\end{array}$ & \multicolumn{2}{c}{$\begin{array}{c}\text { Standard Deviation } \\
\text { (SD) }\end{array}$} \\
\hline Fluoxetine (G1) & 394.55 & 403.56 & 411.06 & 403.77 & $6.25^{\star}$ \\
Imipramine hydrochloride (G2) & 363.69 & 366.81 & 371.14 & 367.47 & $3.07^{\star *}$ \\
Control (G3) & 291.13 & 293.29 & 298.84 & 294.18 & $3.30^{\star *}$ \\
\hline
\end{tabular}

Unifenas Laboratory of Phytopharmaceuticals and Biology and Physiology of Microorganisms, 2009

* indicate $1 \%$ significance level, and ** indicate nonsignificance by the Kruskal-Wallis nonparametric test. 
Table 3 - Fetal encephalic weight (in milligrams)

\begin{tabular}{lccccc}
\hline & $\begin{array}{c}\text { Sample Minimum } \\
\text { (SMin) }\end{array}$ & Median (Med) & $\begin{array}{c}\text { Sample Maximum } \\
\text { (SMax) }\end{array}$ & $\begin{array}{c}\text { Mean } \\
\text { (M) }\end{array}$ & $\begin{array}{c}\text { Standard Deviation } \\
\text { (SD) }\end{array}$ \\
\hline Fluoxetine (G1) & 71.03 & 73.71 & 74.44 & 73.30 & $1.38^{* *}$ \\
Imipramine hydrochloride (G2) & 84.12 & 84.99 & 86.20 & 84.96 & $0.80^{*}$ \\
Control (G3) & 66.89 & 67.38 & 68.02 & 67.43 & $0.41^{* *}$ \\
\hline
\end{tabular}

Unifenas Laboratory of Phytopharmaceuticals and Biology and Physiology of Microorganisms, 2009

* indicate $1 \%$ significance level, and ** indicate nonsignificance by the Kruskal-Wallis nonparametric test.

Administration on the $9^{\text {th }}, 10^{\text {th }}$ and $11^{\text {th }}$ day of pregnancy aimed at establishing a relationship between the so-called "critical" period for rats and the organogenic period in pregnant women (first gestational trimester), when the risk of congenital malformations and severe abortion-inducing damages caused by medication is particularly high. ${ }^{8}$

The development of this study is justified based on the scarcity of information on the embryotoxic effects of antidepressants during pregnancy, especially fluoxetine and imipramine hydrochloride, available in the literature.

A comparison of the toxicity levels of the medications studied can provide useful information for clinical situations in which the use of antidepressants during gestation may become necessary. ${ }^{9}$

In humans, the teratogenic potential of most therapeutic agents remains unknown and is rarely related to specific malformations. It is estimated that $10 \%$ of congenital malformations are attributed to environmental causes, including the use of medication, while $21 \%$ occur due to either genetic or chromosomal abnormalities. ${ }^{25}$

Macroscopic analyses of the fetus, including body weight, both with and without the placenta, and the weights of the placentas and encephala were required to verify the possible effects of drugs on these indicators. Body weight alterations caused by antidepressants have been reported. In 2000, Cash and Brown ${ }^{26}$ discussed the relationship between the use of these antidepressants and the body weight alterations seen in 60 women, with weight loss by fluoxetine and weight gain by imipramine. Further clinical investigations are, however, necessary.

A careful analysis of research conducted on antidepressants and their effects on body weight reveals that, in the short term (six to eight weeks), serotonin reuptake inhibitors, especially fluoxetine, caused a decrease in body weight. However, differently from other groups of antidepressants such as the tricyclic antidepressants, patients did show an increase in body weight in the long term (16-46 weeks). ${ }^{27}$ This supports our findings that fluoxetine and imipramine hydrochloride induce body weight increase in rat fetuses when compared to the control group (Kruskal-Wallis, $\mathrm{p} \leq 0.01$ ).

Altemus et al. prepared an interesting animal model to simulate obsessive-compulsive disorder in which rats were treated with $5 \mathrm{mg} / \mathrm{kg}$ of fluoxetine during 5 weeks. ${ }^{28}$ For comparison purposes, another group was treated with imipramine at the same dose and for the same period of time. They found that the fluoxetine-treated group lost less weight since the animals exercised less. Unlike the first group, the imipramine group lost more weight because of excessive exercise.

Bairy et al. concluded that prenatal fluoxetine administered to rats caused weight loss and a delay in the transient motor development of fetuses, although it did not, however, compromise postnatal behavior, thus supporting the findings of Speiser et al. ${ }^{21,29}$ Most studies demonstrate that fluoxetine-treated rats bear low weight offspring. Vartazarmian et al., however, found no weight alterations in fetuses of fluoxetine-treated rats. ${ }^{30}$

Byrd and Markham treated rats with $12.5 \mathrm{mg} / \mathrm{kg}$ of fluoxetine in the period between the $6^{\text {th }}$ and $15^{\text {th }}$ day of pregnancy. ${ }^{31}$ Fetuses gained weight but showed neither toxicity nor morphological alterations, an outcome similar to ours.

In a recent study, Dannon et al. evaluated two hundred patients with panic disorders who were separated into four groups to test the tolerability of serotonin reuptake inhibitors. ${ }^{32}$ To each group, the following antidepressants were prescribed for 12 months: citalopram, fluoxetine, fluvoxamine and paroxetine. Subjects were weighed at the beginning of the drug treatment and 12 months later. The fluoxetine-treated group lost less weight than the other groups, a fact which may be explained by a lower rate of blood retention. Compared to our results, this suggests that the increase in fetal weight caused by antidepressants can probably be attributed to a higher drug retention in the placenta, thereby leading to lighter effects of the medication on the fetuses.

Differently from the other groups (Kruskal-Wallis test, $\mathrm{p} \leq 0.01$ ), the higher weight of the fluoxetine-treated group may

Table 4 - Neuron counting, per area (40x magnification), of the frontal lobe of fetal encephala.

\begin{tabular}{|c|c|c|c|c|c|}
\hline & $\begin{array}{l}\text { Sample Minimum } \\
\text { (SMin) }\end{array}$ & Median (Med) & $\begin{array}{c}\text { Sample Maximum } \\
\text { (SMax) }\end{array}$ & $\begin{array}{l}\text { Mean } \\
\text { (M) }\end{array}$ & $\begin{array}{c}\text { Standard deviation } \\
\text { (SD) }\end{array}$ \\
\hline Fluoxetine (G1) & 34.01 & 34.44 & 34.64 & 34.38 & $0.24^{*}$ \\
\hline Control (G3) & 36.30 & 36.63 & 37.00 & 36.61 & $0.27^{*}$ \\
\hline
\end{tabular}

Unifenas Laboratory of Phytopharmaceuticals and Biology and Physiology of Microorganisms, 2009.

* indicate $1 \%$ significance level. 
result from the excessive fluoxetine retention by the placental barrier, a fact which is similar to that found by Hendrick et al., who determined the levels of serotonin reuptake inhibitors in the umbilical cord and placenta. ${ }^{33}$ The samples collected from 38 women who used citalopram, fluoxetine and paroxetine showed high concentrations of citalopram and fluoxetine, an indication that these drugs really do cross the placental barrier where they are present at low levels. Similarly, Hostetter et al. found high levels of antidepressants in the placenta and umbilical cord. ${ }^{34}$

The human frontal lobe is home to several complex psychic functions such as emotions, abstraction and generalization. Interestingly enough, frontal lobe alterations have been found in depressive patients since this brain area is involved in attention, psychomotricity, executive capacity, decision making and emotional behavior. ${ }^{35}$

Interestingly, behavioral changes were observed such as sleep disorders in children who had been exposed to antidepressants during the first trimester of gestation; ${ }^{36}$ nevertheless no exposure to antidepressants during pregnancy was associated with internalizing (i.e., emotional reactivity, depression, withdrawal and anxiety) $)^{37}$ and externalizing (i.e., increased activity and aggressive ${ }^{38}$ behaviors.

Based on the facts mentioned above, we quantified the number of neurons present in the frontal lobe of the rat's fetus and found that the use of antidepressants fluoxetine and imipramine hydrochloride significantly decreased the development of neurons when compared to that of the saline control (KruskalWallis test, $\mathrm{p} \leq 0.01$ ) (Table 4 ), thus suggesting that the prescription of antidepressants to pregnant women can induce depression in fetuses due to neurodevelopmental changes. This fact is also confirmed by alterations in encephalic weight, especially in the imipramine-treated group (Kruskal-Wallis test, p $\leq$ 0.01) (Table 3).

Confirming our results, fluoxetine causes an acute increase in serotonin levels, thus leading to a transient reduction in uterine blood flow. This, in turn, decreases the oxygen and nutrient supply to the fetus, reduces its growth and leads it to premature birth. In addition, fluoxetine mainly affects the fetus neural development. ${ }^{39}$

In line with our findings, neurologic changes were also reported by Cabrera-Vera et al., who administered $10 \mathrm{mg} / \mathrm{kg}$ of fluoxetine to rats on the $13^{\text {th }}$ day of pregnancy and found a significant decrease in serotonin levels and in the number of nerve cells of the brain's frontal lobe. ${ }^{40}$

Acebes et al. also administered fluoxetine to rats and found a low nerve cell count in the frontal lobe, although cell numbers were even lower in the parietal and lateral lobes. ${ }^{41}$ Although we only evaluated the frontal lobe, we do believe that significant decreases probably did also occur in other brain regions.

Antidepressants, at the dosage used in this study, caused macroand microscopic alterations in rat fetuses.

Evidently, clinical studies have been carried out to verify whether these medications have teratogenic effects or induce malformations so that practitioners may securely prescribe them in the first trimester of pregnancy.

\section{Conclusion}

It was evident that the use of antidepressants (fluoxetine and imipramine hydrochloride) in rat females during the "critical period" of gestation caused an increase in fetal weight and a decrease in the number of fetal frontal lobe neurons. Results suggest that the use of antidepressants by pregnant women can induce depression in the fetus because of alterations in its neural development.

Therefore, more scientific and clinical knowledge, as well specificity and administration of antidepressants in the first trimester of gestation are needed to reduce macro- and microscopic alteration in fetuses.

\section{Acknowledgements}

The authors wish to thank UNIFENAS and Prof. Vinícius Vieira Vignoli, Prof. Dr. João Evangelista Fiorini and Profa. Dra. Nelma de Mello Silva Oliveira for all their support in the development of this study.

The authors state that there are no conflicts of interest, including specific financial interests and relationships and affiliations relevant to the subject of their manuscript.

Financial support provided by Universidade José do Rosário Vellano UNIFENAS. 
Disclosures

\begin{tabular}{|c|c|c|c|c|c|c|c|}
\hline $\begin{array}{l}\text { Writing group } \\
\text { member }\end{array}$ & Employment & $\begin{array}{c}\text { Research } \\
\text { grant }^{1}\end{array}$ & $\begin{array}{l}\text { Other research grant or } \\
\text { medical continuous } \\
\text { education }^{2}\end{array}$ & $\begin{array}{l}\text { Speaker's } \\
\text { honoraria }\end{array}$ & $\begin{array}{l}\text { Ownership } \\
\text { interest }\end{array}$ & $\begin{array}{l}\text { Consultant/ } \\
\text { Advisory } \\
\text { board }\end{array}$ & Other $^{3}$ \\
\hline $\begin{array}{l}\text { Cátia Aline Silva } \\
\text { Swerts }\end{array}$ & $\begin{array}{l}\text { UNIFENAS } \\
\text { UTI/HUAV }\end{array}$ & - & - & - & - & - & - \\
\hline $\begin{array}{l}\text { Ana Maria } \\
\text { Duarte Dias } \\
\text { Costa }\end{array}$ & UNIFENAS & - & - & - & - & - & - \\
\hline $\begin{array}{l}\text { Alessandra } \\
\text { Esteves }\end{array}$ & UNIFAL & - & - & - & - & - & - \\
\hline $\begin{array}{l}\text { Carla Elaine } \\
\text { Silva Borato }\end{array}$ & UNIPAC & - & - & - & - & - & - \\
\hline $\begin{array}{l}\text { Mário Sérgio } \\
\text { Oliveira Swerts }\end{array}$ & UNIFENAS & - & - & - & - & - & - \\
\hline \multicolumn{8}{|c|}{$\begin{array}{l}{ }^{*} \text { Modest } \\
* * \text { Significant } \\
* * * \text { Significant. Amounts given to the author's institution or to a colleague for research in which the author has participation, not directly to the } \\
\text { author. } \\
\text { Note: UNIFENAS = Universidade José do Rosário Vellano; UTI/HUAV = Unidade de Terapia Intensiva do Hospital Universitário Alzira Velano } \\
\text { da - Universidade José do Rosário Vellano; UNIFAL = Universidade Federal de Alfenas; UNIPAC = Universidade Presidente Antônio Carlos. } \\
\text { For more information, see Instructions for authors. }\end{array}$} \\
\hline
\end{tabular}

References

1. Camacho RS, Cantinelli FS, Ribeiro CS, Cantilino A, Gonsales BK, Braguittoni E, Rennó Jr. R. Psychiatry disorders in pregnancy and puerperium: classification, diagnosis and treatment. Rev Psiquiatr Clin. 2006;33(2):92-102.

2. Osorio-de-Castro CG, Pepe VL, Luiza VL, Cosendey MA, Freitas AM, Miranda FF, Bermudez JA, Leal MdoC. Prescribed and reported drug use during pregnancy. Cad Saude Publica. 2004;20(Suppl1):S73-82.

3 Marcus SM, Flynn HA. Depression, antidepressant medication, and functioning outcomes among pregnant women. Int $J$ Gynaecol Obstet. 2008;100(3):248-51.

4. Fisher B, Rose NC, Carey JC. Principles and practice of teratology for the obstetrician. Clin Obstet Gynecol. 2008;51(1):106-18.

5 Dias VG, Aguni JS, Bezzon AK. Síndrome de Lyell por imipramina: relato de caso. Arq Bras Oftalmol. 2004;67(6):943-5.

6. Czeizel AE, Puhó EH, Acs N, Bánhidy F. Use of specified critical periods of different congenital abnormalities instead of the first trimester concept. Birth Defects Res A Clin Mol Teratol. 2008;82(3):139-46.

7. Zienowicz M, Wisłowska-Stanek A, Lehner M, Taracha E, Maciejak P, Sobolewska A, Szyndler J, Turzyńska D, Walkowiak J, Płaźnik A. Fluoxetine-induced anxiety and nervousness. Pharmacol Rep. 2006;58(1):115-9.

8. Basgül A, Akici A, Uzuner A, Kalaça S, Kavak ZN, Tural A, Oktay S. Drug utilization and teratogenicity risk categories during pregnancy. Adv Ther 2007;24(1):68-80.

9. da-Silva VA, Altenburg SP, Malheiros LR, Thomaz TG, Lindsey CJ. Postnatal development of rats exposed to fluoxetine or venlafaxine during the third week of pregnancy. Braz J Med Biol Res. 1999;32(1):93-8.

10. Esteves A, Prada IL, Carvalho AF. Comparison of the neuron body number of areas brain cortex of dogs. Braz J Vet Res Anim Sci. 2004;41(5):332-8.

11. Avrushchenko MSH. Morphometric study of the Purkinje cells of the canine cerebellar cortex. Biull Eksp Biol Med. 1981;92(9):363-6.

12. Michon JJ, Li ZL, Shioura N, Anderson RJ, Tso MO. A comparative study of methods of photoreceptor morphometry. Invest Ophthalmol Vis Sci. 1991;32(2):280-4.

13. Rabinowicz T, Petetot JM, Gartside PS, Sheyn D, Sheyn T, de CM. Structure of the cerebral cortex in men and women. J Neuropathol Exp Neurol. 2002;61(1):46-57.

14. Zar JH. Biostatical analysis. 2nd ed. Prentice-Hall: Englewood Cliffs; 1984.

15. Zinga D, Phillips SD, Born L Postpartum depression: we know the risks, can it be prevented? Rev Bras Psiquiatr. 2005;27(Suppl 2):S56-64.

16. Bellantuono C, Migliarese G, Imperadore G. Pharmacologic therapy of depression during pregnancy. Recenti Prog Med. 2006;97(2): 94-107.
17. Lisboa SF, Oliveira PE, Costa LC, Venâncio EJ, Moreira EG. Behavioral evaluation of male and female mice pups exposed to fluoxetine during pregnancy and lactation. Pharmacology. 2007;80(1):49-56.

18. van Praag HM, Asnis GM, Kahn RS, Brown SL, Korn M, Friedman JM, Wetzler S. Monoamines and abnormal behaviour. A multi-aminergic perspective. Br J Psychiatry. 1990;157:723-34.

19. Potter WZ, Rudorfer MV, Manji $\mathrm{H}$. The pharmacologic treatment of depression. N Engl J Med. 1991;325(9):633-42.

20. Bergstrom RF, Lemberger L, Farid NA, Wolen RL. Clinical pharmacology and pharmacokinetics of fluoxetine: a review. Br J Psychiatry Suppl. 1988;(3):47-50

21. Bairy KL, Madhyastha S, Ashok KP, Bairy I, Malini S. Developmental and behavioral consequences of prenatal fluoxetine. Pharmacology. 2007;79(1):1-11.

22. Coyle IR, Singer G. The interactive effects of prenatal imipramine exposure and postnatal rearing conditions on behaviour and histology. Psychopharmacologia. 1975;44(3):253-6.

23. DeVane CL, Simpkins JW. Pharmacokinetics of imipramine and its major metabolites in pregnant rats and their fetuses following a single dose Drug Metab Dispos. 1985;13(4):438-42.

24. Pinto FH, Ribeiro RD, Belda Neto FM, do Prado Júnior JC. Comparative study of the behavior of infection in mice, through subcutaneous and intraperitoneal inoculation, using 2 strains of Trypanosoma cruzi. Rev Saude Publica. 1986;20(2):133-40.

25. Halbe HW. Tratado de ginecologia. 2a ed. São Paulo: Roca; 1993.

26. Cash TF, Brown MA. Attitudes about antidepressants: influence of information about weight-related side effects. Percept Mot Skills. 2000;90(2):453-6.

27. Sussman N, Ginsberg DL, Bikoff J. Effects of nefazodone on body weight: a pooled analysis of selective serotonin reuptake inhibitor- and imipraminecontrolled trials. J Clin Psychiatry. 2001;62(4):256-60.

28. Altemus M, Glowa JR, Galliven E, Leong YM, Murphy DL. Effects of serotonergic agents on food-restriction-induced hyperactivity. Pharmacol Biochem Behav. 1996;53(1):123-31.

29. Speiser Z, Fine T, Litinetsky L, Eliash S, Blaugrund E, Cohen S. Differential behavioral syndrome evoked in the rats after multiple doses of SSRI fluoxetine with selective MAO inhibitors rasagiline or selegiline. J Neural Transm. 2008;115(1):107-16

30. Vartazarmian R, Malik S, Baker GB, Boksa P. Long-term effects of fluoxetine or vehicle administration during pregnancy on behavioral outcomes in guinea pig offspring. Psychopharmacology (Berl). 2005;178(2-3):328-38.

31. Byrd RA, Markham JK. Developmental toxicology studies of fluoxetine hydrochloride administered orally to rats and rabbits. Fundam Appl Toxicol. 1994;22(4):511-8. 
32. Dannon PN, Iancu I, Lowengrub K, Gonopolsky Y, Musin E, Grunhaus L, Kotler M. A naturalistic long-term comparison study of selective serotonin reuptake inhibitors in the treatment of panic disorder. Clin Neuropharmacol. 2007;30(6):326-34.

33. Hendrick V, Stowe ZN, Altshuler LL, Hwang S, Lee E, Haynes D. Placental passage of antidepressant medications. Am J Psychiatry. 2003;160(5):9936.

34. Hostetter A, Ritchie JC, Stowe ZN. Amniotic fluid and umbilical cord blood concentrations of antidepressants in three women. Biol Psychiatry. 2000;48(10):1032-4.

35. Rozenthal M, Laks J, Engelhardt E. Neuropsychological aspects of depression. Rev Psiquiatr Rio Gd Sul. 2004;26(2):204-12.

36. Zeskind PS, Stephens LE. Maternal selective serotonin reuptake inhibitor use during pregnancy and newborn neurobehavior. Pediatrics. 2004;113(2):368-75.

37. Misri S, Reebye P, Kendrick K, Carter D, Ryan D, Grunau RE, Oberlander TF. Internalizing behaviors in 4-year-old children exposed in utero to psychotropic medications. Am J Psychiatry. 2006;163(6):1026-32.

38. Oberlander TF, Reebye P, Misri S, Papsdorf M, Kim J, Grunau RE. Externalizing and attentional behaviors in children of depressed mothers treated with a selective serotonin reuptake inhibitor antidepressant during pregnancy. Arch Pediatr Adolesc Med. 2007;161(1):22-9.

39. Morrison JL, Riggs KW, Rurak DW. Fluoxetine during pregnancy: impact on fetal development. Reprod Fertil Dev. 2005;17(6):641-50.

40. Cabrera-Vera TM, Garcia F, Pinto W, Battaglia G. Effect of prenatal fluoxetine (Prozac) exposure on brain serotonin neurons in prepubescent and adult male rat offspring. J Pharmacol Exp Ther. 1997;280(1):138-45.

41. Acebes I, Echevarría E, Abecia LC, Barbero I, Maza JL, Casis L. Comparison of the effects of the administration of fluoxetine and sertraline on the immune markers of the mu opioid receptor in the rat brain. Rev Neurol. 2000;31(10):919-22. 